\title{
ТЕХНОЛОГІЯ ВИКОРИСТАННЯ ДИДАКТИЧНИХ УМОВ АКТИВІЗАЦЇ ПІЗНАВАЛЬНОЇ ДІЯЛЬНОСТІ СТУДЕНТІВ НА ЗАНЯТТЯХ АНГЛІЙСЬКОЇ МОВИ
}

У статті автор теоретично обтрунтовує дидактичні умови, щио забезпечують активізацію пізнавальної діяльності студентів на заняттях з англійської мови. Уточнено поняття «дидактична умова», подано авторське бачення процесу формування мотивації навчання англійської мови студентів неспеціальних факультетів.

Ключові слова: дидактична умова, навчання англійської мови, пізнавальна діяльність.

В статье автор теоретически обосновывает дидактические условия, которые обеспечивают активизацию познавательной деятельности студентов на занятиях по английскому языку. Уточняется понятие «дидактическое условие», раскрывается авторское видение процесса формирования мотивации обучения английского языка студентов неспециальных факультетов.

Ключевые слова: дидактическое условие, обучение английскому языку, познавательная деятельность.

The author substantiates the theory didactic conditions that ensure activation of the cognitive activity of students in classes in English. The notion of "a didactic condition», revealed the author's vision of the formation of motivation of students learning the English language of non-special faculties.

Key words: the condition of didactic, teaching English language, cognitive activity.

Сучасна дидактика витлумачує умови як сукупність чинників, компонентів навчального процесу, що забезпечують успішність навчання. Поняття «дидактичні умови» в сучасній педагогічній думці традиційно розуміється як така ситуація (обставина), за якої компоненти навчального процесу подано в органічному взаємозв'язку і яка надає можливість вчителю плідно викладати, керувати навчальним процесом, а учням - успішно вчитися $[1 ; 8]$. У цьому визначенні правильно інтерпретовано основне призначення дидактичних умов.

Дослідники по-різному трактують дидактичні умови активізації навчання. В. Шморгун визначає такі: бадьорий настрій, життєрадісність, визначений темп роботи, доброзичливий клімат [9]. М. Скаткін виокремлює такі умови: озброєння учнів раціональними прийомами пізнавальної діяльності; поєднання колективної та індивідуальної форм роботи; формування внутрішніх стимулів до навчання, самоосвіти [7]. Специфіка іноземної мови як предмета полягає в тому, що у процесі навчання мови необхідна постійна активізація пізнавальної діяльності студентів, створення умов, які сприяли б активності студентів, викликали інтерес до вивчення даного предмета. Аналіз педагогічної літератури дозволив виявити дидактичні умови активізації пізнавальної діяльності студентів немовних факультетів на заняттях іноземної мови: а) формування мотивації навчання, прагнення до знань, розумової напруги і вияву вольових зусиль у процесі оволодіння знаннями; б) застосування діалогу як активного методу навчання; в) використання міжпредметних зв'язків.

Мотивація визначається як система різних спонук, що включає потреби, мотиви, цілі, інтереси, емоції. Розвиток пізнавальної мотивації забезпечує подолання труднощів студентами у навчальній роботі, викликає їхню пізнавальну активність та ініціативу. 3 появою пізнавальної мотивації відбувається перебудова психологічних процесів сприйняття, пам'яті, мислення, що впливають на ефективність процесів навчання. Формування мотивації до досліджуваного предмета - необхідний процес. Особливо це стосується вивчення іноземної мови на немовному факультеті, осільки мова не $\epsilon$ профілюючим предметом і йому не приділяється достатньо часу. Мотивація позитивно впливає на всі психологічні процеси особистості - увагу, сприйняття, пам'ять, мислення, уяву. Увага з'являється до того, що становить інтерес для особистості. Інтерес - один 3 найдієвіших детермінантів уваги. Сприйняття навчального матеріалу залежить від того, чи сформованою є пізнавальна потреба. Важливу роль при цьому відіграє інструкція, яка допомагає точному сприйняттю матеріалу. Дослідники зазначають, що мислення регулюється системою активних відносин суб'єкта до предмета, що виражаються в мотивації мисленнєвої діяльності [4; 5; 6].

Пізнавальні мотиви $є$ найбільш значущими для навчальної діяльності. В оволодінні іноземною мовою пізнавальні мотиви диференціюються в такий спосіб: інтерес до мови сприяє формуванню мотивів до аналізу мовних явищ, до розвитку лінгвістичного мислення; можливість використання мови як засобу обміну інформацією, отримання знань, зокрема професійних. Учені-психологи виокремлюють такі види мотивації при оволодінні іноземною мовою: 1) цільова мотивація; 2) мотивація, зумовлена усвідомленням учнем (студентом) досягнутого прогресу в оволодінні мовою; 3) мотивація, зумовлена емоційно-особистісним інтересом учня (студента) до країни досліджуваної мови; 4) пізнавальна мотивація, зумовлювана інтересом учня (студента) до глибшого осмислення мовної форми; 5) мотивація, зумовлена прагненням учня (студента) до отримання інформації в найбільш повному обсязі та певній системі; 6) мотивація, породжена почуттям задоволення, яке учень (студент) отримує при виконанні певних видів роботи - інструментальна мотивація; 7) мотивація, зумовлена почуттям естетичного задоволення $[4 ; 5 ; 6]$. 
Розвиток мотивації значною мірою залежить від того, якими засобами і методами користується викладач, який організовує діяльність студентів. Використання певних умов, за яких процес навчання стає цікавим і спонукає до оволодіння знаннями, створює передумови для розвитку мотивації.

Необхідно розвивати загальну мотивацію до вивчення мови. Студентам потрібно бачити i розуміти, яке важливе значення має знання іноземної мови в житті студента - це і спілкування 3 однолітками 3 інших країн, й ознайомлення з культурою інших народів. Однак загальної мотивації недостатньо для розвитку активності, тому слід розвивати і професійну мотивацію.

Студенти економічних спеціальностей зорієнтовані на свою майбутню професію, інтерес для них становить усе, що пов'язане з економікою. Тому одним із провідних мотивів успішності навчання студентів $\epsilon$ інтерес до інформації за фахом. Такий інтерес пов'язаний 3 потребою в майбутній професійній діяльності.

Для розвитку мотивації тексти, із якими працюють студенти, повинні мати такі характеристики: 1) актуальність змісту; 2) новизна; 3) різноманітність.

Вивчення іншомовного матеріалу, обговорення проблем повинно бути актуальним для студентів, а не випадковим або абстрактним. Новизна матеріалу - найважливіша передумова створення інтересу до нього і пізнавальної мотивації.

Однак нове повинне спиратися на вже наявні знання. Навчальний матеріал повинен характеризуватися певним розмаїттям, що забезпечується застосуванням різноманітних прийомів $\mathrm{i}$ методів на занятті при роботі 3 текстом. Наприклад, читання, переклад, розігрування діалогу, дискусії, аудіювання тощо. Крім того, передбачається вивчення текстів, що стосуються різних економічних процесів, розв'язання різних професійних задач іноземною мовою.

Отже, новизна, актуальність та різноманітність змісту іншомовних текстів $є$ необхідною умовою виникнення інтересу і потреби в мовеннєво-мисленнєвій діяльності студента і формуванні мотивації.

Під діалогом як формою спілкування розуміється спільна діяльність учасників, кожен із яких певною мірою визнає загальну для них мету чи хоча б напрям діалогу [4]. На практиці діалогічне спілкування реалізується за допомогою діалогічних знань, завдяки яким відбувається звернення до особистості суб'єкта навчального процесу, розвитку і збагачення іiі досвіду.

Використання діалогічних завдань у навчальній діяльності позитивно впливає на всі пізнавальні процеси особистості - увагу, сприйняття, пам'ять, мислення, що є потужним засобом активізації пізнавальної діяльності.

Діалогічне спілкування є однією з умов формування логічного мислення і виникнення логічних операцій. Розвиток логічних умінь відбувається під час розв'язання діалогічних завдань. Це можуть бути завдання на обгрунтування своєї точки зору, доказ, спростування, пояснення.

Обгрунтувати своє рішення - означає здійснити низку логічних операцій, що сприяють підвищенню продуктивності розумової діяльності.

Розв'яння розумових завдань вимагає інтелектуальної активності суб'єкта, напруги його розумових і вольових сил, пам'яті, уваги.

Завдяки використанню різних видів діалогів у студентів створюються передумови для виклику з пам'яті і перенесення мовного матеріалу в конкретні ситуації під час спілкування. Діалогічні завдання «змушують» учнів активно використовувати всі накопичені знання, вміння і навички.

Діалог як активний метод навчання має переваги порівняно з іншими методами.

1.3 позиції психології - використання діалогів, особливо якщо ситуація моделюється 3 використанням зорової наочності, дозволяє звести до мінімуму мовну інтерференцію. Метод подачі матеріалу в діалогах сприяє розвитку особистої активності учня.

2. 3 позиції педагогіки слід визнати, що викладання іноземної мови методом подання матеріалу в діалогах довело свої переваги. Учні, особливо ті, хто тільки починає вивчати іноземну мову, виявляють бажання говорити цією мовою.

3. 3 позиції лінгвістики - головною метою $є$ усне мовлення, правила якого відрізняються, найчастіше $\epsilon$ більш простими, ніж правила писемного мовлення.

Отже, цінність діалогічних завдань полягає в тому, що вони сприяють «розвитку особистої активності учня», підвищують мотивацію до вивчення мови, забезпечують розвиток усного мовлення.

Навчання діалогічного спілкування студентів - необхідний процес, оскільки саме діалог допомагає студентам активізувати пізнавальну діяльність: розвивати мислення, пам'ять, сприйняття та уявлення. Окрім того, діалог дозволить студентам оволодіти: а) культурою професійного та повсякденного спілкування; б) формулами вітання, ввічливості; в) граматичними структурами; г) професійною лексикою.

Однією 3 дидактичних умов активізації пізнавальної діяльності студентів є використання в навчальному процесі міжпредметних зв'язків.

Міжпредметні зв'язки $є$ не тільки необхідною умовою розвитку системи знань, але і важливим засобом їх здійснення в процесі навчання, сприяючи повноті і міцності знань.

Використання на заняттях відомостей з інших наук активізує сприйняття матеріалу, розкриває нові аспекти вже вивченого. 
Міжпредметні зв'язки сприяють розвитку розумової активності учня (студента). Йому необхідно відтворити в пам'яті ситуацію, у зв'язку 3 якою він вивчав навчальний матеріал 3 іншого предмета. Потім учень (студент) повинен

відібрати з усього курсу ті розділи й ті теми, які йому необхідні для зв'язку з новим предметом. Такі процеси вимагають значного напруження розумової діяльності учня (студента).

Розв'язуючи міжпредметне завдання, студент спочатку аналізує умову, що відбувається через міжпредметний синтез. Наступний крок полягає в тому, що учень (студент) виробляє систему дій за допомогою аналізу та інтеграції знань 3 різних наук. Отриманий результат аналізується i співвідноситися 3 метою завдання. Роздуми над завданням, залучення знань 3 різних наук активізують розумову діяльність студента, сприяють розвитку мислення і мовлення. Використання міжпредметних зв'язків у процесі навчання допомагають розвитку пізнавальної мотивації. В учня (студента) виникає інтерес не тільки до навчального матеріалу, а й до самого процесу вивчення.

Отже, у процесі використання на заняттях міжпредметних зв'язків між економікою й іноземною мовою, інтерес $з$ профілюючого предмета переходить на іноземну мову. Студенти переконуються в тому, що вони цілком можуть застосувати мову в майбутній професійній діяльності, а знання 3 іноземної мови сприяє глибшому оволодіння професією.

Навчальна програма, складена на основі міжпредметних зв'язків, підвищує загальний рівень мотивації, активізує пізнавальну діяльність і сприяє більш продуктивному процесу навчання. Однією 3 дидактичних умов активізації пізнавальної діяльності студентів $\epsilon$ застосування активних методів навчання. До таких науковці відносять ті методи, які дозволяють інтенсифікувати процес розуміння, засвоєння і творчого застосування знань при розв'язанні практичних завдань. В основу активних методів покладено не пасивне сприймання матеріалу, а активне оволодіння знаннями. Активні методи навчання мобілізують інтелектуальні резерви і стимулюють пізнавальну активність учня (студента). Вони також позитивно впливають на розвиток творчого мислення. Загалом, активні методи навчання - це сукупність педагогічних дій i прийомів, спрямованих на організацію навчального процесу, що створює дидактичними засобами умови, які мотивують учнів до самостійного, ініціативного і творчого засвоєння навчального матеріалу в процесі пізнавальної діяльності $[2 ; 3 ; 8]$.

Активні методи спонукають учня (студента) до практичної й розумової діяльності, активізують пізнавальні процеси, розвивають мотивацію, сприяють активності суб'єкта в навчальному процесі.

Залежно від спрямованості на формування знань, умінь, навичок, активні методи, що застосовуються на заняттях іноземної мови, поділяються на імітаційні (ігрові, не ігрові), засновані на моделюванні професійної діяльності (ділова гра, проблемно-пошукові вправи, рольова гра) й неімітаційні (діалог, дискусія, мозковий штурм, різні види самостійних робіт). Викладач повинен стимулювати активність студентів доброзичливим ставленням, пропонувати цікаві види роботи, які спонукають до роздумів, підтримувати увагу та активність. Викладачеві необхідно прагнути до того, щоб дії студентів мали цілеспрямований і свідомий характер. Успішне поєднання діяльності викладача і студентів, виконання визначеної мети з високим результатом забезпечує вдосконалення навчального процесу. Уміти помічати в учня (студента) вияв інтересу до навчання, створювати умови для того, щоб послідовно формувати пізнавальний процес, активізувати думку, ставити проблемне питання, дивувати невідомим і залучати їх до самостійної діяльності - ось завдання викладача [10].

У статті теоретично обгрунтовано дидактичні умови, що забезпечують активізацію пізнавальної діяльності студентів на заняттях з англійської мови. Уточнено поняття «дидактична умова», подано авторське бачення процесу формування мотивації навчання англійської мови студентів неспеціальних факультетів. Окремого розгляду набули активні методи в контексті активізації пізнавальних процесів під час вивчення іноземної мови.

\section{Література}

1. Бердичевский А. Л. Оптимизация системы обучения иностранному языку в педагогическом вузе : [научн.-теорет. пособие] / А. Л. Бердичевский. - М. : Высшая школа, 1989. - 103 с. 2. Беспалько В. П. Системно-методическое обеспечение учебно-воспитательного процесса подготовки специалиста / Владимир Павлович Беспалько. - М. : Высшая школа, 1989. - 141 с. 3. Брушлинский А. В. Мышление и общение / А. В. Брушлинский, В. А. Поликарпов. - Минск : Университетское изд-е, 1990. - 214 с. 4. Выготский Л. С. Педагогическая психология / Лев Семенович Выготский; под ред. В. В. Давыдова. - М. : Педагогика - Пресс, 1999. - 480 с. 5. Гальперин П. Я. Формирование знаний и умственных умений на основе поэтапного усвоения умственных действий / П. Я. Гальперин, Н. Ф. Талызина. - М. : Изд-во МГУ, 1968. - 134 с. б. Леонтьев А. Н. Обучение как проблема психологии / Алексей Николаевич Леонтьев // Вопросы психологии. - 1957. - № 1. С. 17-25. 7. Скаткин М. Н. Активизация познавательной деятельности учащихся в обучении / Михаил Николаевич Скаткин. - М., 1965. - 150 c. 8. Формирование учебной деятельности школьников / под ред. В. Я. Ляудис. - М. : Изд-во МГУ, 1989. - 240 с. 9. Шморгун В. Ф. Активизация учебной деятельности учещихся на уроках : автореф. дис. на соискание ученой степени канд. пед. наук / В. М. Шморгун. - К., 1961. 17 с. 10. Щукина Г. И. Активизация познавательной деятельности учащихся в учебном процессе / Галина Ивановна Щукина. - М. : Просвещение, 1979. - 160 с. 